\title{
C 会場第2日（10月10日）午後の部
}

第41 群 アレルギー（VI）

座長 熊大 石川

睹

185. エステラーゼ染色でみたスギ花粉症の鼻汁

長崎大 ○山口 慶治, 吉見龍一郎

鼻アレルギーは I 型アトピー型の反応が主で, $\operatorname{IgE}$ 抗 体が関与している。IgE 抗体の産生は helper T, suppressor T の制御下に行なわれている。エステラーゼ染 色は, $\mathrm{T}$ リンパ球, 単球, 上皮細胞に陽性を示す。今回 はスギ花粉症の鼻汁をエステラーゼ染色により， Tリン パ球について細胞学的に検討した。

\section{<検査対象 $>$}

昭和 57 年 2 月より 3 月まで, 当科鼻アレルギー外来 受診中のスギ花粉症 17 名（男性 2 名, 女性 15 名, 平均 年龄 29 歳, 標準偏差 8.9 歳) を対象とした。スギ花粉 症の診断には, 病歷, 皮内テスト, 鼻内所見, RAST, その他の諸検查を用いた。エステラーゼ染色用標本は, 発作 1 週間前, 発作第 1 週から第 5 週の各週で各人より 2 標本を採取し, 発作前 12 標本, 発作中 96 標本, 総計 108 標本とした。

\section{<検査方法>}

\section{1）鼻汁の採取方法}

各例 2 本の綿棒を用意し， 1 本は右下甲介上をねじる ように回して鼻汁を採取し，スライドグラスに転がすよ うに塗沫し室温乾燥を行なった。他の 1 本は左下甲介で 同様の手技で標本をつくり，全例を通して同一人が, 毎 週 1 回午後 2 時から 5 時の間に行なった。

2) 染色の原理, 方法

エステラーゼ染色の原理は, 細胞内エステラーゼの存 在下に $\alpha$-ナフチルアセテイトが分解され, 分離したナフ トールがジアゾニウム塩とアゾ色素を形成し，エステラ 一ゼの局在部位に沈着発色する事による。末梢血では, 単球, 血小板が強陽性, $\mathrm{T}$ リンパ球陽性とされている。

染色の実際は, ヌメア作成後室温乾燥し, BFA (PH $\left.6.6,4^{\circ} \mathrm{C}\right)$ で 30 秒固定し水洗, 室温乾燥を行なう。次 に $\alpha$ ナフチルアセティト $60 \mathrm{mg}$, メルセロソルブ 7.5 $\mathrm{m} l$, PBS $133.5 \mathrm{ml}$, 亜硝酸ナトリウム $4 \%$ 液 $4.5 \mathrm{ml}$, パラローズアニリン $4.5 \mathrm{ml}$ 以上の混合液を $\mathrm{PH} 6.1$ に 調整し， 45 分間染色を行ない，水洗し， $2 \%$ チルグリ ーンで核染色後, 脱水, 透徹を行なった。

\section{<結 果>}

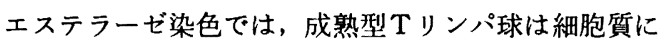
アソ゚色素の大型顆粒を認め, B リンパ球では陰性，単球 は強陽性で均一に染色された。鼻粘膜上皮細胞の細胞質 も陽性に染色された。108 個の各標本を 400 倍の鏡検下 に 10 視野を数えて,エステラーゼ染色陽性細胞の合計を 出した。

$\mathrm{X}$ 軸に発作第 1 週から第 5 週, $\mathrm{Y}$ 軸に鼻粘膜上皮細胞 数でグラフ化すると，第 1 週から第 4 週までは，上皮細 胞数は增加し，第 4 週でピークとなり，第 5 週は減少の 傾向を示した。しかし，危険率 1\%，5\% で検定すると 第 1 と第 2 , 第 2 と第 3 , 第 4 と第 5 の各週間に有意差 はなく，第 1 と第 3 , 第 3 と第 4 の各週間に有意差が見 られた。発作前の 12 標本では, 上皮細胞は全く認めな かった。

発作各週での年齢と上皮細胞数の間には，危険率 $5 \%$ の検定で, 第 1 週から第 5 週の各週で有意の相関は認め られなかった。

108 標本中, 単球は発作中の 5 標本に見られ, $\operatorname{IgE} の$ 産生に関与するTリンパ球は全く検出できなかった。

\section{6. 花粉症発症時のリンパ滤胞の組織学的検討}

東医大 ○沖倉 一彰, 桑島 善郎 西山哲

厚生中央病院 川久保 淳, 船戸 昭利 東医大病理 中田 勇

本年度スギ花粉症, マッ花粉症の 3 月から 5 月までに 来院しくわしい問診を聴取出来た 57 例のうち咽喉症状 併有していたものは 34 例， $59.6 \%$ であった。

これを前回報告した鼻アレルギー 97 例の結果と比較 すると花粉症において咽喉症状が多発する事が知れる。

スギ花粉症において咽喉症状を訴えるものは咽頭全体 に軽度のビマン的発赤を示し，ことにリンパ小節がルビ 一の様に発赤している症例が多く認められる。この所見 は, 我々が第 18 回鼻副鼻腔学会において HD 抗原陽性 鼻アレルギー患者の鼻咽頭へ抗原を直接塗布した際に起 こる咽頭後壁のリンパ小節の発赤, 腫脹の所見と極めて 類似している。

そこで我々は, 本年 3 月 1 日より 4 月 25 日までの咽 
喉症状を併有するスギ花粉症 10 例, 5 月 1 日より 5 月 17 日までのマツ花粉症 2 例の咽頭リンパ小節を採取し 主としてHE 染色によって組織的な検討を施行した。尚 採取は症状極期のものとした。

咽喉症状の内別けは上咽頭がムズムズする 5 例 (41.6 \%), 咽喉頭が痛い3例 (25\%), 咽喉頭がゼイゼイする が 2 例 (16.6\%), 咽喉頭がかわくが 2 例 (16.6\%) であ った。組織学的所見では上皮及び上皮下層の水腫性膨化 及びリンパ細胞の集属紧を中心とする病変でリンパ滤胞 も腫大している。

スギ花粉症のリンパ小節では, 上皮下層にはリンパ細 胞が集属巣を形成しリンパ滤胞も若干腫大している。又 間質結合織部にリンパ細胞浸潤の著るしい場所が認めら れ上皮中間層に水腫性膨化が認められるが好酸球は極め て少なく鼻粘膜の様な特徽的な好酸球浸潤は認めなかっ た。

マッ花粉症でも同様の変化が認められるが程度は若干 軽いようであった。

HD 鼻アレルギー患者の抗原誘発したリンパ小節では 重層扁平上皮の表在部では上皮細胞の一部に水腫性膨化 像があり所によりリンパ細胞集属宩形成が認められる。 上皮下層には間質結合織の一部に細胞浸潤も認め部分的 にリンパ細胞集属采が形成されており, リンパ濾胞も腫 大している。この場合にも好酸球ははなはだ少ない。

即ちスギ花粉症の組織像に比べ程度は若干高度である が組織所見としては同様な病態を示していると考えられ る。

ちなみにへビースモーカーに見られた慢性顆粒性咽頭 炎患者のリンパ小節を採取し組織学的に検討すると重層 扁平上皮覆に一般に非特異性慢性炎による細胞浸潤があ り花粉症に比してリンパ球数はやや少なく形質細胞数が 多い事が認められる。前記のような激しいリンパ細胞浸 潤は認められない。

昨年報告した 97 例においても原因別に考察するとや はり花粉症が多く又季節性に発症するものに咽喉症状が 多発することを報告したが，やはり鼻アレルギーにおけ る咽喉症状は濃厚な抗原刺激を受けた場合惹起される事 が考えられ, 又上咽頭のようなリンパ上皮系においては 濃厚な抗原刺激に対しリンパ球を中心とした反応として 上皮及び上皮下層の水腫様病変ならびにリンパ細胞集属 鉴形成という病態が出現する。

澌問 今野 炤義（秋田大）
(1) 花粉症発症時の咽頭滤胞に好酸球, 肥満細胞は多 くないとの事であるが，咽頭の抗原誘発時にみられる咽 頭のカユミ, イライラ感, 痛みに chemical mediator の関与はないのか? リンンパ滤胞以外の部位の中咽頭 粘膜の組織像はどうか?

応答 沖倉 一彰 (東医大)

(1) HD 抗原液にて鼻咽頭を誘発した際にも，やはり， 好酸球の出現は少なかった。(2) ケミカルメディエータ 一の関与も考えられるが補体が関与している事も考えら れる。(3) 慢性炎の小節は採取しているが, 全くの正常 者からは採取はしていない。

\section{7. 副鼾腔炎をもつ鼻アレルギー患者一上顎洞粘膜の} 抗原誘発による病理組織学的変化一

熊本大 ○渡辺敬, 田中 憲雄 神崎 順徳, 石川 哮

「アレルギー性副鼻腔炎」の概念はまだ確立されては いないが，I型アレルギー反応が副鼻腔粘膜でも起こる ということは十分予想されることである。自然孔を通じ て侵入した抗原が粘膜の局所 $\operatorname{IgE}$ 抗体と結合し, 好塩基 性細胞の脱顆粒現象によって chemical mediator が放出 された場合, 副鼻腔粘膜においても, 浮腫, 分泌六進, 血管拡張などの現象が引き起こされるはずである。我々 は, 昨年の当学会で, 副鼻腔炎手術例について, アレル ギー検査を含む臨床所見と病理組織学的所見とを対比さ せ，I 型アレルギー特有の組織所見が, 臨床像における アレルギーと相関していることを報告した。臨床像にお けるアレルギー群と非アレルギー群をくらべると，好酸 球浸潤, 杯細胞増生においては明らかに差があり, 浮腫 もアレルギー群でやや高度であるが, 好塩基性細胞の数 では明確な差がなく，脱顆粒像が問題となると思われ た。

そこで，副鼻腔粘膜におけるI 型アレルギーを証明す るために, 上顎洞手術時, 粘膜に抗原をチャレンジさせ てその変化を肉眼的, 病理組織学的に観察した。対象は 抗原が確定している鼻アレルギー患者で，いずれもレ線 上副鼻腔に陰影をもつ 3 症例である。抗原は第 1 例と第 2 例ではダ二, 第 3 例では八ウスダストである。上頡洞 造影は行なっていないが，第 1 例で明らかなポリープ様 陰影を認めた。術中, 第 1 例の両側, 第 2 例の右側洞粘 膜にポリープを見た。

上䫟洞前壁を開空し, 分泌物を吸引除去した後, 抗原 
ディスクを置いた。約 10 分間観察した後,この部の粘 膜を切除し固定した。誘発部以外の粘膜もコントロール として固定した。採取粘膜を切片作製し, Hematoxylin-

Eosin および Toluisin blue にて染色鏡検した。 肉眼的な粘膜の変化は, 浮腫の増強, 毛細血管の拡張, 墏液性分泌物の貯留などである。

病理組織学的に見ると全体として, 上皮の増生は少な く, 杯細胞は軽度の増加, 浮腫は中等度に増強している。 好酸球の浸潤は症例 2 の左側を除いてはよく見られてお $\eta$, 好塩基性細胞も多い。誘発による変化としては, 好 酸球が毛細血管内一集簇している像や，血管外一遊出し つつある像が特徵的で, 好塩基性細胞には脱顆粒像が多 く見られた。浮腫の程度は誘発によりわずかに增強して いる。

以上のことをまとめると，誘発による組織像の変化と しては, 1. 好塩基性細胞の脱顆粒, 2. 浮腫の増強, 3 . 好酸球の小血管内集簇および血管外への遊走ということ になる。これはI型アレルギーの発症機序に一致してお り, 抗原抗体反応の結果としての chemical mediator の作用と解される。しかも，コントロールの組織像より わかるように副鼻腔粘膜には，I型アレルギーの結果と しての病変が見られている。

今回の実験結果より, 鼻アレルギ一患者の副鼻腔病変 はI 型アレルギーとしての特徵を備え，抗原への曝露に よってアナフィラキシー反応が惹起されることが証明さ れた。

このような副鼻腔炎を「アレルギー性副鼻腔炎」と称 してもいいのではないかと考える。すなわち，1）鼻了 レルギー症状をもつ。2）アレルギー歴の存在，3）アレ ルゲンテストによる原因抗原の確定。4）副鼻腔もレ線 上炎症像がある。さらにいえば，5）レ線陰影は高率に ポリープ様を呈する。6) 手術所見では浮腫が強く, 上 頡洞内にポリープを見ることが多い。

この上うな副鼻腔炎は本質的には可逆的であると思わ れるが, 自然孔の狭小化, 二次的な感染により難治性で あることも考えられる。

減感作療法をはじめとするアレルギーの治療によりど のように変化するかについて, 今後, 多くの症例で検討 することが必要であろう。

\section{質問 兵 行雄（奈良医大）}

腺細胞の変化と基底膜の変化があったでしょうか。 芯答 渡辺敬（熊大）
誘発による杯細胞の変化は非誘発部に比べて差がなか った。ただ云々アレルギー例では杯細胞の増生が見られ ている。腺については今回検討してない。杯細胞, 腺, 基底膜の変化については今後見ていきたい。

\section{質問 今野 昭義（秋田大）}

(1) “アレルギー性副鼻腔炎”があるとすれば抗原は 自然孔を通って副鼻腔に入るのか? 鼻粘膜から吸収さ れた抗原が血行性に副鼻腔粘膜に到達するのか?

(2) 抗原誘発状態が持続し, “アレルギー性副鼻腔炎” が成立したとすればどのような組織像が予想されるの か?

\section{応答 渡辺敬（熊 大）}

短時間の変化では今回の組織像となっているが，時間 が経過した場合は，例えば今回のコントロール部のよう な像になっていくと考えられる。

質問 朝倉 光司（札医大）

skin test と同様に general の感作状態をあらわすも のか, あるいは鼻粘膜誘発と同様に局所の感作状態をあ らわすものか。

応答渡辺敬（熊大）

抗原の濃度には差があるが，自然孔を通して上效洞内 一は常時抗原が入っていると考えられ，鼻アレルギーと 同質のものと考える。従って誘発反応も鼻アレルギーと 同様の変化が起こったと考えていいと思う。

睤問 福田 諭 (北大)

鼻アレルギーの診断には鼻汁好酸球, 鼻誘発テストな ど局所の検查成績が重要視されている。アレルギー性副 鼻腔炎を開洞前に診断するためのクラィテリアは?

\section{応答 渡辺敬（熊 大）}

（アレルギー性副鼻腔炎のクラィテリアは，臨床的に 今回示している。）答弁はしていません。

188. 粪アレルギー患者のリンパ球幼若化反応における ヒトIa 様抗原の役割

旭川医大 $\bigcirc$ 高橋 光明, 熊井 恵美 海野 徳二

旭川医大第 2 病理 池田 久実

$<$ 目 的 $>$

アレルギー学的諸検査で抗原を確定したダニアレルギ 一患者リンパ球の抗原認識におけるヒ卜 Ia 様抗原の役 割を検討するため, 特異的抗原による in vitro のリン 八球幼若化反応 (lymphocyte proliferative reaction 以 
下 LPR) を観察し，その LPR におけるヒトIa 様抗原 の役割をヒト Ia 様抗原に対する単クローン抗体を用い て検討した。

\section{<実験方法>}

1) 単クローン抗体

使用した 3 種の単クローン抗体（7B6，8B3，9C4）は DR 4 の homo 接合体のヒト末様リンバ球を E-B virus で transform して得た培養 B リンパ芽球様細胞 (Wa 細 胞）をマウスに免疫し，その脾細胞と myeloma cell （P 3/63-Ag 8-653）を細胞融合して得られた。3 種の単 クローン抗体はすべて allo 抗原性を検出せず, 7B6 抗 体は全てのヒト Ia 様抗原分子上の共通にある抗原決定 基を検出し 8B3 抗体, 9C4 抗体はヒト Ia 様抗原の一 部を検出する抗体であることをWa 細胞を用いた 2 重 抗体法及び sequential coprecipitation 法により明らか にしている。

\section{2) LPR}

リンパ球微量培養法で検討した。即ち，患者末血をへ パリン採取し, Ficoll-Conray 比重遠心法にてリンパ球 を分離した後，血小板を除去し $10 \%$ ヒト $\mathrm{AB}$ 血清が RPMI に suspend し 96 穴 microplate に分注 $\left(2 \times 10^{5}\right.$ 細胞/well) の上, 特異的抗原 (鳥居製乾燥ダ二抗原 0.77 $\mathrm{mg}$ を 20 倍希釈）を $10 \mu l$ 加え 5 日培養の後 ${ }^{3} \mathrm{H}$-thymidine を加え 18 時間後 havest してその DNA 合成人 の取り込みを cpm で測定した。単クローン抗体の LPR への影響は抗体付加時の cpm の低下を阻止率であらわ して検討した。

\section{<結 果>}

ダニアレルギー患者 20 名と正常者 8 名について LPR を検討した結果, 患者群は 20 名中 17 名が $1,700 \mathrm{cpm}$ 以上（最低 $384 \mathrm{cpm}$, 最高 $25,552 \mathrm{cpm}$, 平均 $7,230 \mathrm{cpm}$ ) の反応がみられ, 正常者群は 1 例が $1,700 \mathrm{cpm}$ 以外全 て $1,000 \mathrm{cpm}$ 以下であった。尚, 抗原非付加時の cpm はほとんどすべて $1,000 \mathrm{cpm}$ 以下であった。1,700 cpm 以上の LPR が認められた患者 17 名について単クローン 抗体の LPR への影響を検討した。7B6 抗体は 1 例を除 き全例に LPR の阻止がみられ, 8B3 抗体では 7 例で阻 止され 8 例は阻止が認められなかった。9C4 抗体では 1 例を除きほぼ全例に阻止が認められなかった。そこでほ ぼ半数が阻止された 8B3 抗体について 8B3 抗体で LPR が阻止された A 群と阻止されなかった B 群の 2 群にわけ て臨床的検討をした。 total IgE, 特異的 IgE 抗体, 皮 内反応閾值について両群に差はみられなかったが特異的
減感作療法の効果についてはA 群 2/6（1 名は未施行）, B 群は 7/7(1) に効果がみられ，B 群に減感作療法有効例 が多い傾向にあった。

\section{<考 察〉}

7B6 抗体の結果より全ての $\mathrm{DR}$ 及び DR 様抗原上の 共通にある抗原決定基に対する抗体の場合 LPR は阻止 されることは, アレルギー患者リンパ球の抗原認識とそ の幼若化反応においてヒト Ia 様抗原が重要な働きをし ていることが明らかになった。一方 8B3 抗体のような 一部の $\mathrm{DR}$ 及び DR 様抗原に対する単クローン抗体の 場合，LPR の阻止系が人により差がみられ，しかも減 感作療法の効果にも関連する傾向にあることは人の D 領 域の多様性が反映していること，及び減感作療法効果に D領域が一定の役割をはたしている可能性も考えられ た。

兵問 竹中 洋 (京府医大)

(1)この系は条件が非常に複雑と考えます。HLA 抗 体の target となる細胞についておのおのの検討をされ たか。

(2) 抗血清処理の条件によって LPR が変化すると考 えるが，この点での検討はなされたか。

応答 高橋 光明（旭医大）

LPR はリンパ球の subset を分けて検討していない。

第 42 群 アレルギー（VII）

座長 東女医大 石井 哲夫

189. 并アレルギーにおける自律神経受容体の動態 関西医大 ○石部 司, 奥野 吉昭 山下 敏夫, 熊沢 忠躬 神戸大薬理嘢 高義, 田中千賀子

\section{<緒 言 $>$}

生理実験, 薬理実験などより鼻粘膜には $\alpha_{1}, \beta$ アドレ ナリン受容体, ムスカリン性アセチルコリン受容体（以 下 $\alpha_{1}, \beta, \mathrm{mACh}$ 受容体と略）が存在する事が示唆され ているが，定量に成功した報告はない。 ${ }^{3} \mathrm{H}$ でラベルし たリガンドを用いる結合実験にて，これら交感神経系， 副交感神経系の鼻粘膜における受容体量の定量にはじめ て成功し，鼻アレルギーにおけるこれらの受容体量の変 化を検討したので報告した。

<方 法 $>$

25 例の下甲介粘膜所見がほぼ正常に近いと思われる 